\title{
Investigating Major Drivers of Performance in Community Water Projects: A Case of Water Projects in Saku Sub County, Marsabit County, Kenya
}

\author{
Abdi Adan Hagarsu, Luketero Stephen Wanyonyi, and Reuben Wambua Kikwatha
}

\begin{abstract}
The purpose of this study was to determine the major drivers of performance in community water projects - a case of water projects in Saku sub county, Marsabit County, Kenya. The study investigated; the role of management planning, availability of funding, community participation and projects governance policies on performance of community water projects in Saku Sub County. The study used Community Development theories' and adopted a descriptive research design. The target population for this study was 106 with a sample of 84 respondents. The study use questionnaire where quantitative data was analyzed using SPSS 25.0, qualitative data using thematic content and inferential data using multiple regression.

The research found that stakeholder involvement and planning all levels of project implementation influence performance of community water projects in Saku Sub County in Marsabit County, Kenya to a great extent. The study further found that trained, adequate human resource influence performance of community water projects to a very great extent. The research found that frequency of meetings; project ownership; and level of involvement influence performance of community water projects to a great extent. The study concluded that management planning had the greatest influence on performance of community water projects followed by funding, and then project governing policies while community participation had the least influence on the performance of community water projects. The study recommends inclusive planning at all levels of the project cycle and request the government develops mechanisms to curb corruption occurrences especially in the face of project implementation.
\end{abstract}

\section{INTRODUCTION}

Development is a concept that is of great concern to communities and the globe has embraced this agenda with not only the implementation of Millennium Development Goals (MDGs) of 2000 but also the sustainable development goals of 2015. The United Nations' defines community development as the process that is meant to provide conditions of economic and social progress for the entire community.

In Kenya, the Constituency Development Fund (CDF) was launched in year 2013 after the general election as depicted in the new constitution. The available devolved kitty was the Constituency development fund as outlined under the CDF Act 2003, Kenya Gazette Supplement No.

Published on October 25, 2020.

Abdi Adan Hagarsu, University of Nairobi, Kenya. (corresponding e-mail: abdihagarsu2015@gmail.com)

Luketero Stephen Wanyonyi, University of Nairobi, Kenya.

Reuben Wambua Kikwatha, University of Nairobi, Kenya.
107 (Act No. 11) tasked with ironing out regional imbalances brought about by patronage politics [1]. CDF provides funds to constituencies through the respective members of the National Assembly. County Governments have the objective of helping to improve the livelihood of the locals either through direct participation or providing funding to supplement the national government's allocation to the various sectors. Most of these funds provided by County Government are project driven short-term funds, which do not factor in the whole funding mechanism policies that will ensure that such projects become sustainable after the county funds have been withdrawn. To ensure project performance, it is crucial to have well thought out strategy that only looks at how a Community water projects is completed, but also the means to continue with the project after the county funds have been withdrawn [2].

\section{A. Statement of the Problem}

Community water projects in Marsabit County have not been performing well where cases of mismanagement of resource due to malpractice have been reported. Cases of delayed completion of the projects have been reported in the county citing various challenges that such as delays in involving experts from the community during the initiation of community development based projects towards success [3].

Some of the community water projects in Saku Sub County in Marsabit County have not been completed since 2016 to date due the financial challenges which are caused by reduced funding from the donors, mismanagement of resource by the management committees and lack of clear governing policies to implement the project (Galm Qampise - program officer-Kivulini Trust). Despite the poor performance community development based project in Saku Sub county in Marsabit County in Kenya, there is scarce literature in the Kenya done in the sub county. Most of the available literatures focus on other counties. For example, Karithi [4] examined factors influencing performance of community water projects in Tigania Central District, Meru County, Kenya, Cheruiyot [5] examined factors influencing perfomance of community based water projects in Bomet County and Githua [6] assessed the factors influencing performance of community water projects in Njoro Sub County. This study was therefore essential to the community members of the Marsabit county whose projects seem not to last long enough to serve them. Hence this study sought to bridge these gaps and establish factors influencing the performance of Community water projects in Saku Sub County in Marsabit County, Kenya. 


\section{B. Objectives of the Study}

i. To examine the influence of management planning on the performance of Community water projects in Saku Sub County in Marsabit County, Kenya.

ii. To investigate the influence of funding on the performance of Community water projects in Saku Sub County in Marsabit County, Kenya.

iii. To evaluate the influence of community participation on the performance of Community water projects in Saku Sub County in Marsabit County, Kenya.

iv. To determine the influence of the projects governance policies on the performance of Community water projects in Saku Sub County in Marsabit County, Kenya.

\section{LITERATURE REVIEW}

\section{A. Performance of Community Water Projects}

According to Richardson [7], the performance of CWPs is considered in relation to achievement of project set objectives in the constraints of time, cost and quality. During project implementation performance indicators inform the project team on the project's progress as it gears towards achieving the ultimate goals and/or objectives.

The performance of CDPs in view of the time and cost incurred and the quality to show can also be influenced by external factors. According to Burke [8], failure to plan in project management has a ripple effect on a project's survival that remains uncontrollable until it has been dealt with from the basics. It is a project plan that shows a project's end from the beginning. According to their study Usman, Kamau and Mireri [9] state that the inability to implement governing policies is a major setback to project performance in developing countries. Policies can have a positive or negative influence on project performance.

\section{B. Management Planning and Performance of Community Water Projects}

The planning process of management is a central endeavor of project management. The contribution of the planning process to project performance is major as planning forms the foundation on which the entire project rests. It provides a clear picture of the project that is the project scope, its beginning, its means and its end. It outlines and describes the project activities, how they will be accomplished and the expected outcome or end products [10]. The main purpose of the planning process is to identify and define major project tasks, estimate time and resources required to carry them out and come up with a framework for managing reviewing and controlling the project activities. This study seeks to bridge this gap in previous studies by establishing the effect of management planning on the performance of community water projects.

\section{Funding and Performance of Community Water Projects}

Karithi [4] in his study on factors influencing performance of community water projects in Tigania Central Sub-County established that more rural people were involved in addressing their own development, the study failed to point out the effect of funding on performance of community water projects. In addition, Odoyo [11] in his review on the factors affecting performance of community water projects in Kenya failed to establish the effect of funding on performance of community water projects. This study therefore seeks to bridge these gaps by establishing the effect of funding on the performance of community water projects.

\section{Community Participation and Performance of Community Water Projects}

Kaufman and Poulin [12] states that the involvement of community members in community initiatives is a requirement that cannot be ignored owing to the fact that these projects are by the communities and for the communities. The involvement emanates right from project initiation, execution and closure.

Studies by Maimuna [13] and Njogu [14] who studied factors influencing the performance of community water project in isiolo and meru county respectively failed to highlight the effect of community participation on performance of community water projects. This study therefore seeks to bridge these gaps by establishing the effect of community participation on the performance of community water projects.

\section{E. Project Governance Policies and Performance of Community Water Projects}

Studies by Oyugi [15] and Usman, Kamau and Mireri [9] reported that government policies and procedures in Nigeria put in place to guide in the national development initiatives have not been effectively implemented. However, these studies failed to show how project governing policies affect performance of community water projects. This study therefore seeks to bridge these gaps by establishing the effect of project governing policies 'on the performance of community water projects.

\section{F. Theoretical Framework}

\section{Community Development Theories}

This theory originated from the work of Lewin [15] whose theory stated, 'people support what they help create.'

The theory was applicant to the study as it upheld the place of community in any involvement. Its strength is on the fact that it proves the participation of people in initiatives and therefore relevant to Community water projects. It however does not outline how the participation and close involvement from the beginning is done.

This study specifically utilize Stages of Community Development Groups theory [17] which considers groups or organization as community that must go through four stages of pseudo where conflict are avoided, chaotic stage, emptiness where members embrace the need to work for interest of group and finally authentic stage where community enhance their understanding and proceed to achieve progress. 


\section{G. Conceptual Framework}

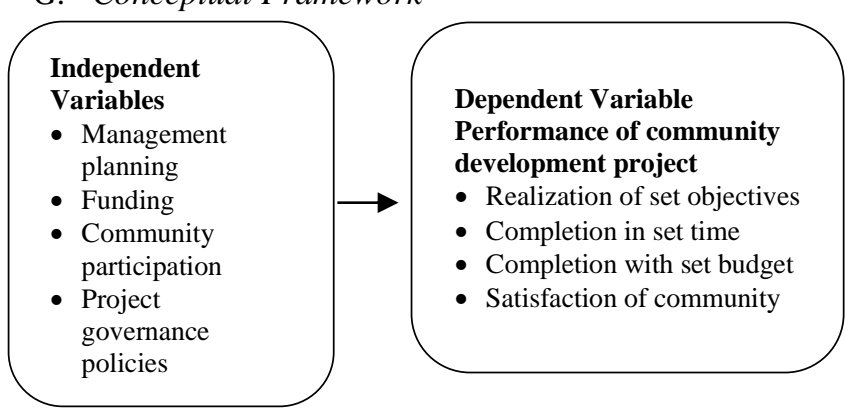

\section{RESEARCH METHODOLOGY}

\section{A. Research Design}

The study adopted a descriptive research design. Creswell and Plano Clark [18] states that descriptive research determines and reports the way things are. Descriptive research design was therefore significant in this study as it informed the researcher of the exact position of the phenomenon that is being studied without altering its state. The description in the research design sought to answer such questions as what, how, when, and where.

\section{B. Sample Size and Sampling Procedure}

Bryman and Bell [19] state that the rule of the thumb in sampling is to obtain as big a sample as possible. Taking a population size of 106, the researcher adopted the Ya-mane Taro formula to get a sample of 84 respondents.

The study first used proportional allocation where each population group $(\mathrm{Np})$ was divided by the total populace $(\mathrm{N})$ to get a ratio in which each group was picked at and later multiplied by the sample size gotten. That is for instance, for project officers the sample was $9 / 106 \times 84=7$.

Stratified sampling methods were also used for the selection of the study respondents.

\begin{tabular}{cccc}
\multicolumn{4}{c}{ TABLE 1: SAMPLING FRAME } \\
\hline & Frequency & Ratio & Sample \\
\hline Project officers & 9 & 0.79 & 7 \\
Field officers & 12 & 0.79 & 10 \\
Community leaders & 22 & 0.79 & 17 \\
Project committee's & 37 & 0.79 & 29 \\
$\quad$ representatives & 10 & 0.79 & 8 \\
County government officials & 16 & 0.79 & 13 \\
Religious leaders & $\mathbf{1 0 6}$ & 0.79 & $\mathbf{8 4}$ \\
Total & & &
\end{tabular}

\section{Research Instrument}

For this study, the researcher made use of questionnaires in the gathering of primary data. The choice of this instrument is informed by its advantages such as it is free from the bias of the interviewee and respondents had ample time to give well thought out answers.

\section{Pilot Testing of Instruments}

The pilot study enabled the researcher to probe the feasibility of the methods and procedures that were used in the main study. The accuracy of data to be collected is largely dependent on the data collection instruments in terms of validity and reliability which can only be established through a pilot test [20].

\section{E. Validity of the Research Instrument}

The researcher used Face validity to study's questionnaire with the help the researcher's supervisor, giving it a subjective overview. Further, the current study also looked into the content validity of the choice research tools through persistent consultations with raters from University of Nairobi with respect to readability, clarity and comprehensiveness of measurement on the construct of interest.

\section{F. Reliability of the Research Instrument}

The study embraced the use of internal consistency technique employing Cronbach Alpha to examine the reliability of research questionnaire that was utilized in the current research study.

\section{G. Data collection procedure}

Data was collected using a questionnaire with both open ended and closed ended questions structured to meet the objectives of the study and administered to the respondent through the research assistant.

\section{H. Data Analysis Technique}

Data was analyzed using Statistical Package for Social Sciences (SPSS Version 25.0). Referencing of all received questionnaires was done and coding of questionnaire items was done for facilitating data entry. After data cleaning which entailed checking for errors in entry, descriptive statistics such as frequencies, percentages, mean score and standard deviation was estimated for all the quantitative variables and information presented inform of tables. The qualitative data from the open-ended questions was analyzed using thematic content analysis and presented in narrative form.

Inferential data analysis was done using multiple regression analysis. Multiple regression analysis was used to establish the relations between the independent and dependent variables.

\section{Ethical Considerations}

To conduct this study, the researcher sought both an introductory letter from the graduate school, University of Nairobi to ascertain that he was a bona fide student and a permit from the National Commission for Science, Technology and Innovation (NACOSTI). Permission was also sought from intended respondents to indicate their willingness to participate and their anonymity when it comes to answering the research instruments was upheld.

\section{DAta AnAlysis, Presentation, And INTERPRETATION OF FINDINGS}

\section{A. Respondents' Gender}

The findings revealed that $55.3 \%$ of the respondents were male while $44.7 \%$ were female.

\section{B. Respondents' Age Bracket}

The findings show that $27.0 \%$ of the respondents were aged 46 yrs. and above, $26.3 \%$ were aged between 26-35 yrs., $25.7 \%$ were aged between $18-25$ yrs. while $21.1 \%$ were aged between $36-45$ yrs. 


\section{Respondents' Highest Level of Education}

From the findings, $29.6 \%$ of the respondents had attained a degree, $25.7 \%$ had reached the postgraduate level, $23.0 \%$ had attained the certificate/diploma and $21.7 \%$ had reached the ' $\mathrm{O}$ ' level. $\mathrm{S}$

\section{Management Planning}

Table 2: Extent Management Planning Influence Performance of

\begin{tabular}{ccc}
\multicolumn{3}{c}{ COMMUNITY WATER PROJECTS } \\
\hline & Frequency & Percent \\
\hline Not at all & 9 & 12.5 \\
Low extent & 10 & 13.2 \\
Moderate extent & 6 & 7.9 \\
Great extent & 25 & 34.2 \\
Very great extent & 24 & 32.2 \\
Total & $\mathbf{7 3}$ & $\mathbf{1 0 0 . 0}$ \\
\hline
\end{tabular}

The finding from data analysis shows that $34.2 \%$ of the respondents indicated that management planning influences the performance of community water projects in Saku Sub County in Marsabit County, Kenya to a great extent, $32.2 \%$ indicated to a very great extent, $13.2 \%$ indicated to low extent, $12.5 \%$ indicated not at all and $7.9 \%$ indicated to a moderate extent. This implies that management planning influences the performance of community water projects in Saku Sub County to a great extent.

\section{E. Funding}

TABLE 3: EXTENT FUNDING INFLUENCE PERFORMANCE OF COMMUNITY

\begin{tabular}{ccc} 
& WATER PROJECTS & \\
\hline & Frequency & Percent \\
\hline Not at all & 11 & 15.1 \\
Low extent & 7 & 9.9 \\
Moderate extent & 10 & 13.2 \\
Great extent & 25 & 34.9 \\
Very great extent & 20 & 27.0 \\
Total & $\mathbf{7 3}$ & $\mathbf{1 0 0 . 0}$ \\
\hline
\end{tabular}

The finding form data shows that $34.9 \%$ of the respondents indicated that funding influences performance of community water projects in Saku Sub County in Marsabit County, Kenya to a great extent, $27.0 \%$ indicated to a very great extent, $15.1 \%$ specified that not at all, $13.2 \%$ indicated to a moderate extent and $9.9 \%$ indicated to a low extent. This implies that funding influences performance of community water projects in Saku Sub County in Marsabit County, Kenya to a great extent.

\section{F. Community Participation}

TABLE 4: INFLUENCE OF COMMUNITY PARTICIPATION ASPECTS ON PERFORMANCE OF COMMUNITY WATER PROJECTS

\begin{tabular}{ccc}
\hline & Mean & Std. Dev. \\
\hline Level of involvement & 3.559 & 0.968 \\
Frequency of meetings & 4.046 & 0.783 \\
Project ownership & 3.763 & 0.791 \\
Decision making & 3.467 & 0.914 \\
\hline
\end{tabular}

The findings from data analysis show that the respondents indicated that frequency of meetings as shown by a mean of 4.046; project ownership as shown by a mean of 3.763 ; and level of involvement as shown by a mean of 3.559 influence performance of community water projects in Saku Sub County of Marsabit County to a great extent. The respondents further indicated that decision making as shown by a mean of 3.467 influences performance of community water projects in Saku Sub County of Marsabit County to a moderate extent.

\section{G. Project governing policies}

TABLE 5: EXTENT PROJECTS GOVERNING POLICIES INFLUENCE PERFORMANCE OF COMMUNITY WATER PROJECT

\begin{tabular}{ccc}
\multicolumn{3}{c}{ PERFORMANCE OF COMMUNITY WATER PROJECT } \\
\hline Frequency & Percent \\
\hline Not at all & 6 & 7.9 \\
Low extent & 7 & 9.2 \\
Moderate extent & 10 & 13.8 \\
Great extent & 28 & 38.2 \\
Very great extent & 23 & 30.9 \\
Total & $\mathbf{7 3}$ & $\mathbf{1 0 0 . 0}$ \\
\hline
\end{tabular}

The findings revealed that $38.2 \%$ of the respondents indicated that projects governing policies influence performance of community water projects in Saku Sub County in Marsabit County to a great extent, $30.9 \%$ indicated to a very great extent, $13.8 \%$ indicated to a moderate extent, $9.2 \%$ indicated to a low extent, $7.9 \%$ indicated not at all. This implies that that projects governing policies influence performance of community water projects in Saku Sub County in Marsabit County to a great extent.

\section{H. 4Performance of Community Water Projects}

The study further required to know the trend of aspects of performance of community water projects in Saku Sub County of Marsabit County for the last 5 years.

TABLE 6: TREND OF COMMUNITY WATER PROJECTS PERFORMANCE IN SAKU SUB COUNTY

\begin{tabular}{ccc}
\hline & Mean & Std. Dev. \\
\hline Realization of set objectives & 3.684 & 0.814 \\
Completion in set time & 3.605 & 0.728 \\
Completion with set budget & 3.836 & 0.554 \\
Satisfaction of community members & 3.743 & 0.815 \\
\hline
\end{tabular}

The findings show that the respondents indicated that completion with set budget as presented by a mean score of 3.836; satisfaction of community members as presented by a mean score of 3.743 ; realization of set objectives as presented by a mean score of 3.684; and completion in set time as presented by a mean score of 3.605 have improved for the last 5 years.

\section{Multiple Regression Analysis} TABLE 7: MODEL SUMMARY.ANOVA TEST RESULTS

\begin{tabular}{cccccc}
\multicolumn{6}{c}{ TABLE 7: MODEL SUMMARY.ANOVA TEST RESULTS } \\
\hline Model & $\begin{array}{c}\text { Sum of } \\
\text { Squares }\end{array}$ & df & $\begin{array}{c}\text { Mean } \\
\text { Square }\end{array}$ & F & Sig. \\
\hline Regression & 299.121 & 4 & 74.780 & 47.076 & .000 \\
Residual & 108.017 & 68 & 1.588 & & \\
Total & $\mathbf{4 0 7 . 1 3 8}$ & $\mathbf{7 2}$ & & & \\
\hline
\end{tabular}

From the findings, the independent variables were statistically significant predicting the dependent variable since adjusted $\mathrm{R}$ square was 0.719 . This implied that $71.9 \%$ of variations in performance of community water projects in Saku Sub County in Marsabit County, Kenya are explained by management planning, funding, community participation and project governing policies. Other factors influencing performance of community water projects in Saku Sub County in Marsabit County, Kenya that were not covered in this study accounted for $28.1 \%$ which form the basis for further studies. From the ANOVA, p-value was 0.000 and F-calculated was 47.076. Since p-value was less than 0.05 and the F-calculated was greater than F-critical (2.5066), then the regression relationship was significant in determining how management planning, funding, 
community participation and project governing policies influenced performance of community water projects in Saku Sub County in Marsabit County, Kenya.

The regression equation established that taking (management planning, funding, community participation and project governing policies) at constant, performance of community water projects in Saku Sub County will be 1.267. The findings presented also show that increase in the management planning leads to 0.821 increase in the score of performance of community water projects in Saku Sub County if all other variables are held constant. This variable was significant since the $\mathrm{p}$-value $0.027<0.05$.

\section{DISCUSSION OF FINDINGS}

The research found that stakeholder involvement and planning all levels of project implementation influence performance of community water projects in Saku Sub County in Marsabit County, Kenya to a great extent. The study further found that trained, adequate human resource influence performance of community water projects to a very great extent. The research found that frequency of meetings; project ownership; and level of involvement influence performance of community water projects to a great extent.

\section{CONCLUSIONS AND RECOMMENDATION}

The study concludes that management planning has a positive and significant influence on the performance of performance of Community water projects in Saku Sub County in Marsabit County, Kenya. The study concluded that financial management mechanisms such as requirements for detailed proposals with clear objectives and goals for the use of funds; prioritization of projects funded within the budgets and strategic plans are to be upheld.

The study concluded that funding has a significant influence on the performance of Community water projects in Saku Sub County in Marsabit County, Kenya. The study deduces that appropriate controls and safeguards should also be put in place to prevent the misuse and inappropriate application of finance appropriated and given as conditional and unconditional grants. Some of the controls in question include audit and budgeting.

The study further concluded that community participation influences the performance of community water projects in Saku Sub County in Marsabit County, Kenya. The study deduces that it is necessary for project teams to involve the community in all aspects of the community water project. Community participation ensures strong support for effective performance of the community project. Further, emphasis on community participation in the development and management of community water projects is a sure sign that the project has a bright chance of functioning optimally on a sustainable basis.

The study further concluded that projects governing policies have a significant and positive influence on the performance of community water projects in Saku Sub County in Marsabit County, Kenya. The study concluded that that policy making and implementation that involves key development practitioners bears much and vices like corruption and lack of constant policy updates affects these processes.

The study recommends inclusive planning at all levels of the project cycle and request the government develops mechanisms to curb corruption occurrences especially in the face of project implementation. The study also recommends furthers studies to be conducted on others counties to compare the results

\section{REFERENCES}

[1] Landi, F., Calvani, R., Picca, A., Tosato, M., D’Angelo, E., Martone, A. M., \& Acampora, N. (2018). Relationship between cardiovascular health metrics and physical performance in community-living people: Results from the Longevity check-up (Lookup) 7+ project. Scientific reports, 8.

[2] Del Brutto, O. H., Mera, R. M., Gillman, J., Zambrano, M., \& Ha, J. E. (2016). Oily fish intake and cognitive performance in communitydwelling older adults: the Atahualpa Project. Journal of community health, 41(1), 82-86.

[3] Kaimenyi, M. D., \& Wanyonyi, L. S. (2019). Factors influencing sustainability of community based county projects in Kenya: A case of Isiolo North Sub County, Isiolo County. International Academic Journal of Information Sciences and Project Management, 3(3), 164 184.

[4] Jacob, Sabastian Karithi; GICHUKI, Nathan. Factors Influencing Performance Of Community Water Projects In Tigania Central SubCouty, Meru County, Kenya. European Journal of Social Sciences Studies, [S.1.], sep. 2017.

[5] Cheruiyot, S. C. (2016). Factors influencing performance of community based water projects in Bomet county. University of Nairobi, Kenya.

[6] Githua, R. W. \& Wanyoike, D. M. (2015). Factors influencing performance of community water projects in Njoro Sub County. International Journal of Economics, Commerce and Management, 3(2), 23-39.

[7] Richardson, G. L. (2011). Project Management Theory and Practise. New York: CRC Press.

[8] Burke, R. (2014). Project Management Planning and Control Techniques. 4th edition. New Delhi.

[9] Usman, N. D., Kamau, P. K. \& Mireri, C. (2014). The impact of Policy and Procedural Framework on Project Perfomance Within the Building Industry in Abuja Nigeria. International Journal of Engineering Research \& Technology (IJERT), 3(5), 2086-2091.

[10] Gudda, P. (2011). A Guide to Project Monitoring and Evaluation. Bloomington: Author House.

[11] Phinehas, N., \& Odoyo, O. (2019). A Review on the Factors Affecting Performance of Community Water Projects in Kenya. Journal of Public Policy \& Governance, 3(2), 43 - 60. Kaufman, S. \& Poulin, J. (2014). Citizen Participation in prevention activities: A path model. Journal of Community Psychology, 22, 359374.

[12] Maimuna (2017) Factors influencing performance of water projects in arid and semi-arid areas a case of Ewaso $\mathrm{Ng}$ 'iro North borehole projects, Isiolo County, Kenya, International Academic Journal of Information Sciences and Project Management| Volume 2, Issue 1, pp. 217-238

[13] Njogu (2018) The influence of community participation on project performance of Ruiri water projects, Meru County, Kenya.

[14] Oyugi, S. (2012). How to Register a Group. Retrieved May 27, 2016, from Standard Digital http://www.standardmedia.co.ke/lifestyle/article/2000072403/howto-register-a-group

[15] Lewin, K. (1952). Group decision and social change. Readings in social psychology. Newcombe and Hartley (Eds.), Henry Holt, New York.

[16] Peck, N. (1987). Dropout prevention: What we have learned.

[17] Creswell, J. W. \& Plano Clark, V. L. (2011). Designing and conducting mixed methods research. Los Angeles, CA: Sage.

[18] Bryman, A. \& Bell, E. (2011). Business research methods (2nd ed.). New York: Oxford R. J. Vidmar. (August 1992). On the use of atmospheric plasmas as electromagnetic.

[19] Kumar, R. (2019). Research methodology: A step-by-step guide for beginners. Sage Publications Limited. 


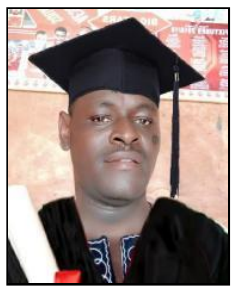

Mr. Abdi Adan Hagarsu was born in Sericho location, Isiolo County on $24^{\text {th }}$ Dec 1979 . Holder of masters of Arts in Project Planning\& Management (2020) and a bachelor's degree in Adult Education \& Community Development (2018) from university of Nairobi and a diploma in community development (2004) from Kenya institute of social work and community development.

He has over fifteen years of working experience having worked with action aid Kenya for 11years as project officer (2004-2015), with IEBC as deputy returning officer for 3 months (2017), worked with kivulini trust organization as program officer for one year (2018) and currently working as curriculum support and quality assurance officer in county Government of Marsabit in the Department of Education. (Dec 2018 to Date)

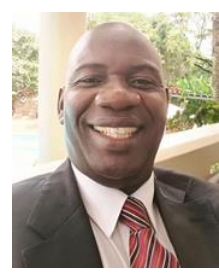

Prof. Luketero Stephen Wanyonyi was born on $3^{\text {rd }}$ march 1971, Professor Luketero is a Senior Lecturer and Director School of Mathematics, University of Nairobi. Kenya. He holds a bachelor of science in Mathematics, Master of science in Mathematics, Master of Business Administration, (MBA), and a Doctorate in Mathematics.

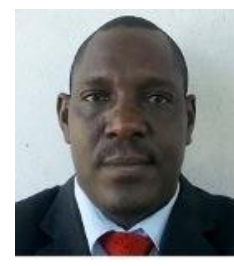

Dr Reuben Wambua Kikwatha was born in Kitui County, Kenya in 1975. He holds a doctorate in Project planning and Management, specializing in Project Planning Design, and Implementation from the University of Nairobi. He also holds a Master's degree in Project Planning and Management from The University of Nairobi, Bachelor's degree in Sociology from Moi University and a post graduate diploma in Community development.

Dr Kikwatha is currently a lecturer at the University of Nairobi, teaching project planning and Management in Open, Distance and eLearning (ODeL) campus, He has over 20 years of experience implementing Wildlife Conservation and community development projects in different parts of Kenya. Dr Kikwatha is a member of Kenya Association of Project Managers (KAPM) and Kenya Association of Fundraisers (KAF). He is also a member of different community development forums and academic mentorship groups. 